\section{REFERENCES}

Alkjaersig, N. (19:-0). In Conference on Thrombolytic Agents, edited by H. R. Roberts and J. D. Geraty, p. 136. Chapel Hill.

Assali, N. S., Rauramo, L., and Peltonen, T. (1960). Amer. F. Obstet. Gynec, 79, 86.

Astrup, T. (1956). Lancet, 2, 565.

Benz, J. J. (1968). Thrombos. Diathes. haemorrh. (Stuttg.), 19, 226.

Biezenski, J. J. (1960). J. clin. Path., 13, 220.

Biezenski, J. J., and Moore, H. C. (1958). F. clin. Path., 11, 306.

Brakman, P. (1966). Amer. 7. Obstet. Gynec., 94, 14.

Brakman, P., and Astrup, $\mathrm{T}$ (1963). Scand. F. clin. Lab. Invest., 15,

Brakman, P., and Astrup, T. (1963). Scand. f. clin. Lab. Invest., 15,
Brown, C. J., and Stalker, A. L. (1968). Proceedings of the International Conference on Microcirculation, Gothenburg, Sweden, 1968. Gothenburg, Sweden.

Cash, J. D. (1966). Brit. med. F., 2, 502.

Cash, J. D., and Leask, E. (1967). Ұ. clin. Path., 20, 209.

Chesley, L. C., and Chesley, E. R. (1939). Amer. F. Physiol., 127, 731.

Das, P. C., Allan, A. G. E., Woodfield, D. G., and Cash, J. D. (1967). Brit. med. F., 4, 718.

Das, P. C., and Cash, J. D. (1968). In preparation.

Devi, B., Jennison, R. F., and Langley, F. A. (1968). F. clin. Path., 21, , B2.,

Ellis, B. C., and Stransky, A. (1961). F. Lab. clin. Med., 58, 477.

El-Mahallawi, M. N., Seif El-Din, D., Mahran, M., Sabour, M. S., and Fadel, H. E. (1968). Obstet. and Gynec., 31, 621.

Fearnley, G. R. (1953). Nature (Lond.), 172, 544 .

Gans, H., and Lowman, J. T. (1967). Blood, 29, 526.

Gillman, T., Naidoo, S. S., and Hathorn, M. (1959). Lancet, 2, 70.

Ginsburg, J., and Duncan, S. L. B. (1967). Cardiovasc. Res., 1, 132.

Gitlin, D., Landing, B. H., and Whipple, A. (1953). ₹. exp. Med., 97, 163.

Hammond, J. D S., and Verel, D. (1959). Brit. F. Haemat., 5, 431.

Herschlein, H. J., and Steichele, D. F. (1968). Thrombos. Diathes. haemorrh. (Stuttg.), 19, 248.

Huckabee, W. E. (1962). Amer. F. Obstet. Gynec., 84, 1623.

Hytten, F. E., and Leitch, I. (1964). The Physiology of Human Pregnancy. Oxford.
Kawano, T., Morimoto, K., and Uemuld, Y. (1968). Nature (Lond.), $217,253$.

Lewis, J. H., Ferguson, E. E., and Schonfeld, C. (1961). F. Lab. clin. Med. 58, 247.

Mackay, A. V. P., Das, P. C., Myerscough, P. R., and Cash, J. D. (1967). F. clin. Path., 20, 227.

McKay, D. G., Margaretten, W., and Rothenberg, J. (1964). Lab. Invest., 13, 54.

McLennan, C. E. (1943). Amer. 7. Obstet. Gynec., 45, 568.

Merskey, C., Kleiner, G. J., and Johnson, A. J. (1966). Blood, 28, 1.

Metcalfe, J., Romney, S. L., Ramsey, L. H., Reid, D. E., and Burwell, C. S. (1955). F clin. Invest., 34, 1632.

Murakami, M. (1965). Fap. 7. clin. Path., 13, 542.

Naeye, R. L. (1961). New Engl. 7. Med., 265; 867.

Niléhn, J. E., and Nilsson, I. M. (1964). Scand. F. Haemat., 1, 313.

Nilsson, I. M., Krook, H., Sternby, N.-H., Söderberg, E., and Söderström, N. (1961). Acta med. scand., 169, 323.

Nilsson, I. M., and Kullander, S. (1967). Acta obstet. gynec. scand., 46, 273.

Olesen, E. S. (1961). Scand. 7. clin. Lab. Invest., 13, 410.

Ratnof, O. D. and Menzie, C. (1951). 7. Lab. clin. Med., 37, 316.

Seitchik, J. (1967). Amer. F. Obstet. Gynec., 97, 701.

Shaper, A. G., Kear, J., Macintosh, D. M., and Kyobe, J. (1965). F. Obstet. Gynaec. Brit. Cwlth, 75, 433.

Shaper, A. G., Macintosh, D. M., Evans, C. M., and Kyobe, J. (1965). Lancet, 2, 706.

Sherry, S., Fletcher, A. P., and Alkjaersig, N. (1959). Physiol. Rev., 39, 343.

Simcock, M. J., and Forster, F. M. C. (1967). Med. F. Aust., 2, 971.

Turpie, A. G. G., Forbes, C. D., and McNicol, G. P. (1967). Brit. med. F., 3, 646 .

Winner, W. (1965), Obstet. gynec. Surv., 20, 545.

Woodfield, D. G., Cole, S. K., and Cash, J. D. (1968). Amer. F. Obstet. Gynec., 102, 440 .

Woodrow, J. C., and Finn, R. (1966). Brit. F. Haemat., 12, 297.

Wright, H. P., Osborn, S. B., and Edmonds, D. G. (1950). Surg. Gynec. Obstet., 90, 481 .

\title{
Hypercalciuria Relative to Total Solutes in Nephrolithiasis
}

\author{
L. C. ISAACSON, ${ }^{*}$ M.D., PH.D., M.R.C.P.ED.
}

Summary : Urines obtained from normal controls, from patients with calcium-containing renal stones, and from acutely ill patients suffering from various other renal or electrolyte disorders were analysed for $\mathrm{Na}, \mathrm{K}, \mathrm{NH}_{4}$, $\mathrm{Ca}, \mathrm{Mg}$, inorganic phosphate and sulphate, $\mathrm{pH}$, and osmolality.

The stone-formers' urines were found to be characterized by hypercalciuria relative to $\mathrm{Na}, \mathrm{K}, \mathrm{Mg}, \mathrm{SO}_{4}$, osmolality, and ionic strength. Hypercalciuria relative to osmolality was a more consistent finding than hypercalciuria relative to $\mathrm{Na}$.

These findings are in keeping with the supposition that calcium-containing renal stones occur in urine saturated with calcium salts.

\section{Introduction}

Hypercalciuria, relative to osmolality, characterizes the urines of patients with calcific nephrolithiasis (Isaacson, Modlin, and Jackson, 1966 ; Chambers and Dormandy, 1967). Hypercalciuria relative to sodium also characterizes these urines (Modlin, 1967). As $\mathrm{NaCl}$ normally contributes substantially to the urinary osmolality, it is not clear which is the primary feature: hypercalciuria relative to all the urinary solutes or hypercalciuria relative essentially to $\mathrm{Na}$ alone.

Light can be thrown on this problem by comparison of stone-formers' urines, not with those of normal subjects in

* Endocrine-Metabolic Research Group, Department of Medicine, University of Cape Town. Present address: Department of Physiology, University of Cape Town. which $\mathrm{Na}$ and osmolar concentrations are usually highly correlated, but rather with those of a non-stone-forming population in which these concentrations are not correlated. Differentiation of the stone-formers' urines from those of this population will then be best accomplished by whichever of these indices ( $\mathrm{Ca} /$ osmolar or $\mathrm{Ca} / \mathrm{Na}$ ratio) is the more fundamental.

Acutely ill patients suffering from a variety of renal or electrolyte disorders (but not with renal stones) constitute such a population. Comparison of their urines with those of patients with calcium-containing renal stones shows that hypercalciuria relative to the total solutes, rather than to $\mathrm{Na}$ alone, is the primary feature characterizing the urines of patients with nephrolithiasis.

\section{Methods}

Random urine samples were obtained from 42 normal individuals and from 50 acutely ill patients in hospital. The sole criterion for selection of these patients was that they suffered from renal or electrolyte disorders, and did not have renal stones. These patients have been briefly reported on, and their various diagnoses listed, in an earlier report (Isaacson et al., 1966).

In addition 24-hour urines were collected from 21 patients with calcium-containing renal stones. None of these subjects was acutely ill, nor did they have any of the conditions known to predispose to renal stone formation.

All urines were collected under toluene and stored at $4^{\circ} \mathrm{C}$. while awaiting analysis. The volume of each 24-hour aliquot was measured. Each urine was analysed for $\mathrm{pH}, \mathrm{Na}, \mathrm{K}, \mathrm{NH}_{4}$, 
$\mathrm{Ca}, \mathrm{Mg}$, inorganic phosphate and sulphate, and osmolality. The methods of chemical estimation have been described previously (Isaacson et al., 1966). pH was measured on a model G Beckman $\mathrm{pH}$ meter.

The ionic strength and the ionic (non-urea) fraction of the osmolality of each urine were then calculated as described elsewhere (Isaacson, 1968a).

\section{Results}

The urinary composition in all three groups of subjects is described in Tables I and II.

TABLE I.-Composition of 24-Hour Urines Obtained From 21 Patients with Calcium-containing Renal Stones

\begin{tabular}{|c|c|c|c|c|c|}
\hline & & & & Mean & S.D. \\
\hline 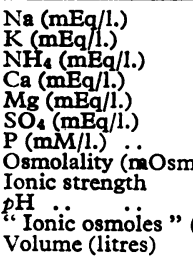 & $\begin{array}{l}\because \\
\because \\
\because \\
\because \\
\ddot{n} / \mathrm{kg} . \\
\ddot{0} \\
\ddot{\%}) \\
\cdots\end{array}$ & $\begin{array}{c}\because \\
\because \\
\cdots \\
\cdots \\
\ddot{2} \\
\cdots \\
\cdots \\
\cdots\end{array}$ & $\begin{array}{l}\because \\
\because \\
\because \\
\because \\
\because \\
\because \\
\because \\
\because \\
\therefore\end{array}$ & $\begin{array}{c}96 \\
30 \\
33 \\
7 \cdot 8 \\
5 \cdot 7 \\
24 \\
19 \\
532 \\
0 \cdot 196 \\
6 \cdot 29 \\
61 \cdot 6 \\
1 \cdot 60\end{array}$ & $\begin{array}{l}28 \\
13 \\
11 \\
3 \cdot 4 \\
3 \cdot 2 \\
14 \cdot 6 \\
10 \cdot 4 \\
169 \\
0 \cdot 059 \\
0 \cdot 94 \\
6 \cdot 7 \\
0 \cdot 59\end{array}$ \\
\hline
\end{tabular}

"Ionic osmoles" $=$ Non-urea fraction of the osmolality.

TABLE II.-Comparison of Composition of Random Urines Obtained From Normal Controls and From Acutely Ill Patients

\begin{tabular}{|c|c|c|c|c|c|}
\hline & \multicolumn{2}{|c|}{ Normals (42) } & \multicolumn{2}{|c|}{ Patients (50) } & \multirow{2}{*}{$\mathbf{P}$} \\
\hline & Mean & S.D. & Mean & S.D. & \\
\hline 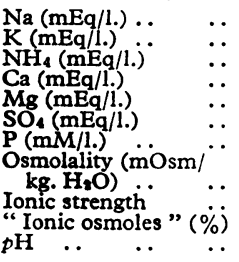 & $\begin{array}{c}132 \\
56 \\
21 \\
4 \cdot 6 \\
7 \cdot 1 \\
29 \\
15 \\
718 \\
0 \cdot 248 \\
60 \cdot 2 \\
5 \cdot 96\end{array}$ & $\begin{array}{c}70 \\
30 \\
12 \\
3 \cdot 1 \\
3 \cdot 2 \\
13 \\
9 \\
276 \\
0 \cdot 103 \\
9 \cdot 8 \\
0 \cdot 63\end{array}$ & $\begin{array}{c}91 \\
79 \\
29 \\
3 \cdot 3 \\
6 \cdot 9 \\
56 \\
15 \\
695 \\
0 \cdot 246 \\
56 \cdot 3 \\
6 \cdot 15\end{array}$ & $\begin{array}{c}65 \\
56 \\
18 \\
3 \cdot 9 \\
4 \cdot 1 \\
37 \\
11 \\
207 \\
0 \cdot 034 \\
19 \cdot 5 \\
0.88\end{array}$ & $\begin{array}{l}<0.001 \\
<0.01 \\
<0.01 \\
= \\
<\overline{0.001} \\
= \\
= \\
-\end{array}$ \\
\hline
\end{tabular}

The stone-formers excreted 4.1 to $18.0 \mathrm{mEq} \mathrm{Ca} / 24$ hours (mean $11.5 \mathrm{mEq}$ ). Though of lower osmolality, these urines contained a greater mean concentration of calcium than those of the other subjects.

Osmolar and sodium concentrations were highly correlated $(r=0.77)$ in the urines obtained from the normal subjects.

The urines of the acutely ill patients were of similar osmolality, but had lower $\mathrm{Na}$ and higher $\mathrm{K}, \mathrm{NH}_{4}$, and $\mathrm{SO}_{4}$ concentrations than those of the normals. The fraction of the

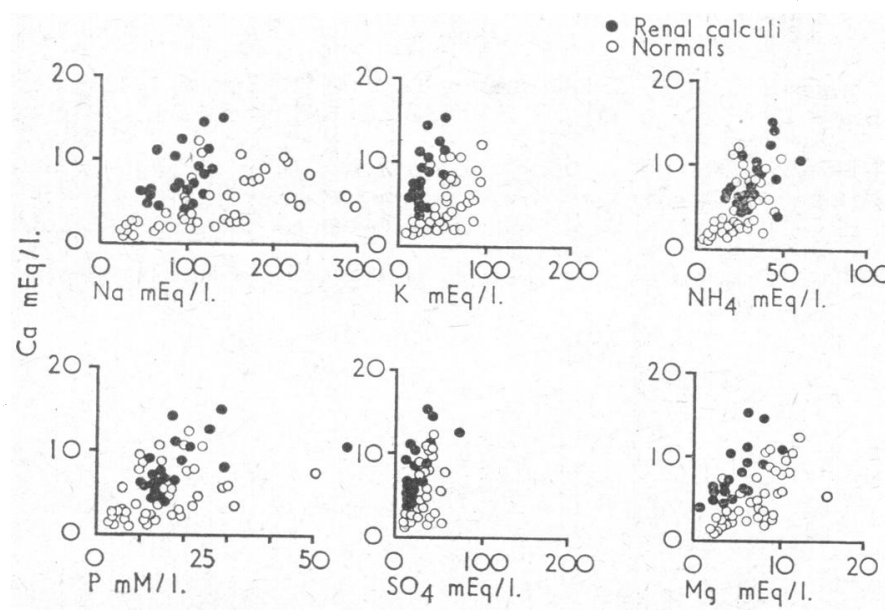

FIG. 1.-Relationships between the urinary concentrations of $\mathrm{Ca}$ and other ionic constituents in stone-formers and normal controls.

C urinary osmolality contributed by the ionic constituents, and both the absolute amoun:s and the relative proportions of each of the ionic constituents, showed considerably greater variability in these patients than in either the normals or the stone-formers (Tables I and II). Urinary osmolar and sodium concentrations were not interrelated $(r=0.05)$.

At any urinary calcium concentration the stone-formers' urines contained lesser concentrations of $\mathrm{Na}, \mathrm{K}, \mathrm{SO}_{4}$, and $\mathrm{Mg}$, and were of lower osmolality and ionic strength, than those of the normal subjects (Figs. 1, 2, and 3).

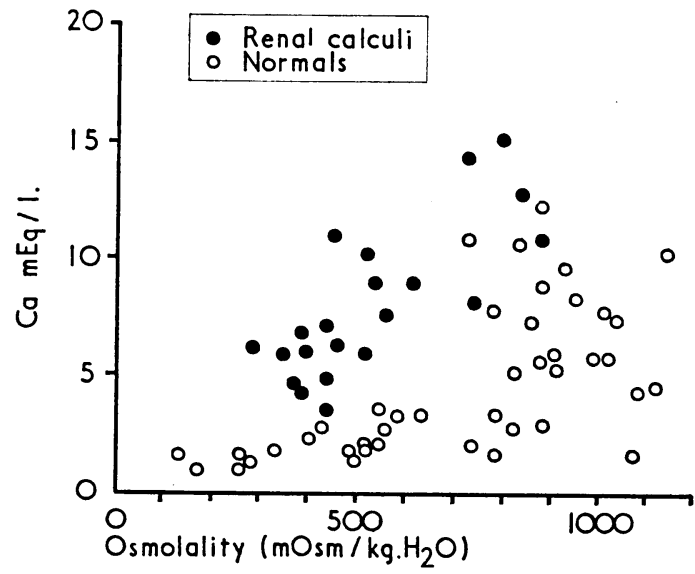

Fig. 2.-Urinary $\mathrm{Ca}$ and osmolar concentrations in stoneformers and normal controls.

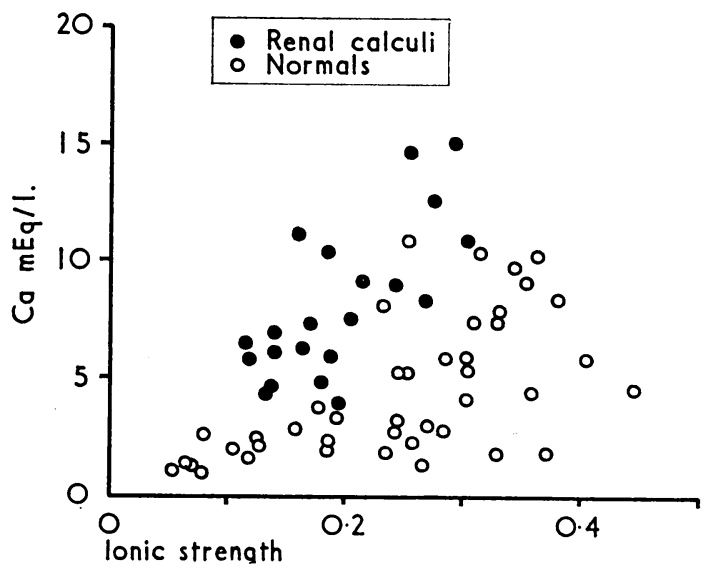

FIG. 3.-Urinary $\mathrm{Ca}$ concentrations and ionic strengths in stone-formers and normal controls.

Similarly, at comparable urinary calcium concentrations the stone-formers' urines contained lesser concentrations of $\mathrm{K}, \mathrm{Mg}$, and $\mathrm{SO}_{4}$, and were of lower osmolality and ionic strength, than those of the acutely ill patients; there was no difference in their $\mathrm{Na}$ concentrations, however. Most of the non-stoneforming patients had lower urinary calcium concentrations than any of the stone-formers; the $\mathrm{Ca} / \mathrm{Na}$ ratios in many of these urines were, however, as high as those found in the stoneformers.

\section{Discussion}

It has been shown elsewhere (Isaacson, 1968b) that 24-hour urines obtained from patients with calcium-containing renal stones contain less $\mathrm{Na}, \mathrm{K}, \mathrm{Mg}$, inorganic phosphate, and occasionally sulphate, and are of lower osmolality and ionic strength than those of normal subjects excreting the same amount of calcium. Almost identical features appear on comparison of stone-formers' urines with random normal urines of equal calcium concentration (Figs. 1, 2, and 3). The relationships between $\mathrm{Ca}$ and $\mathrm{K}, \mathrm{Mg}$, osmolality, and ionic strength differ- 
entiate the urines of the stone-formers from those of the normals as effectively as does the relationship between $\mathrm{Ca}$ and $\mathrm{Na}$.

These findings in themselves throw considerable doubt on the validity of the suggestion of a unique role for $\mathrm{Na}$ in the genesis of calcium-containing renal stones (Modlin, 1967). Further evidence against this hypothesis emerges on comparison of the composition of stone-formers' urines with that of patients suffering from other renal or electrolyte disorders. These urines differ from normal random urines in that no correlation

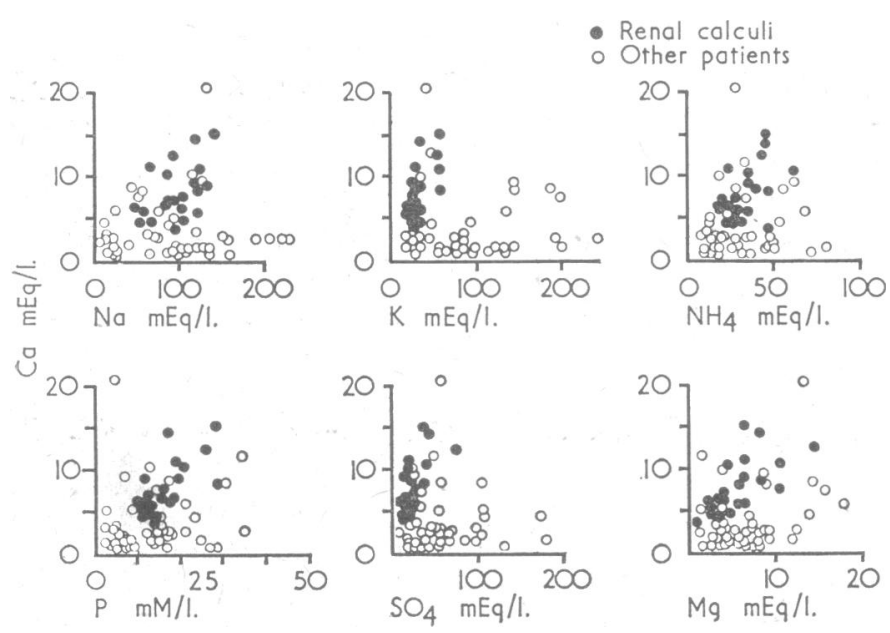

FIG. 4.-Relationships between the urinary concentrations of $\mathrm{Ca}$ and other ionic constituents in stone-formers and in acutely ill patients. (In this, and in Figs. 5 and 6, the single "other" patient with a urinary calcium concentration of $20 \mathrm{mEq} / 1$. had idiopathic hypercalciuria.)

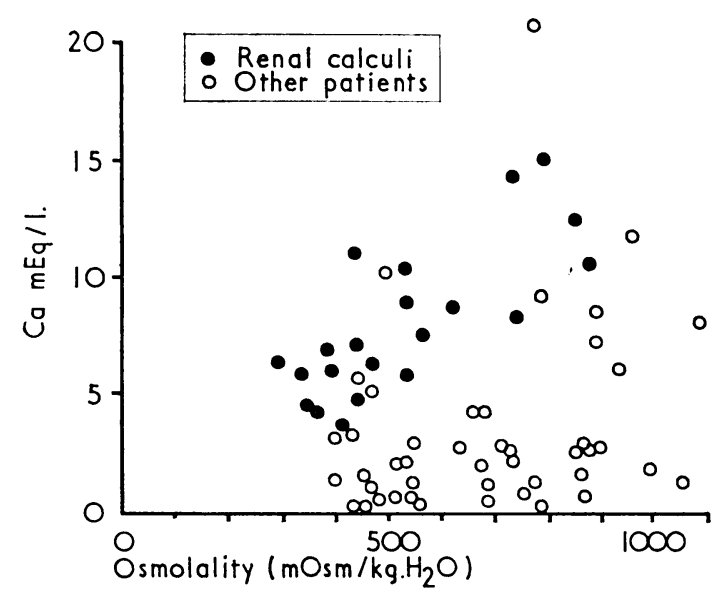

FIG. 5.-Urinary $\mathrm{Ca}$ and osmolar concentrations in stoneformers and in the other non-stone-forming acutely ill patients.

exists between their $\mathrm{Na}$ and osmolar concentrations. Comparison of these urines with those of the stone-formers thus necessarily reveals which of the two relationships-that is, hypercalciuria relative to $\mathrm{Na}$ or hypercalciuria relative to osmolality-is the more characteristic of nephrolithiasis. The findings (Figs. 4 and 5) clearly favour the latter.

The urines of the non-stone-forming acutely ill patients differ from those of the normal controls in yet two other respects.
In these urines the ionic (non-urea) fraction of the urinary osmolality is very much more variable than in the normals, as are also both the absolute concentrations and relative proportions of the various ionic constituents (Table II). Despite this greater intrinsic variability, comparison of these urines with those of the stone-formers again shows the latter to be characterized by hypercalciuria relative to a number of ionic constituents, as well as to osmolality and ionic strength (Figs. 4, 5 , and 6).

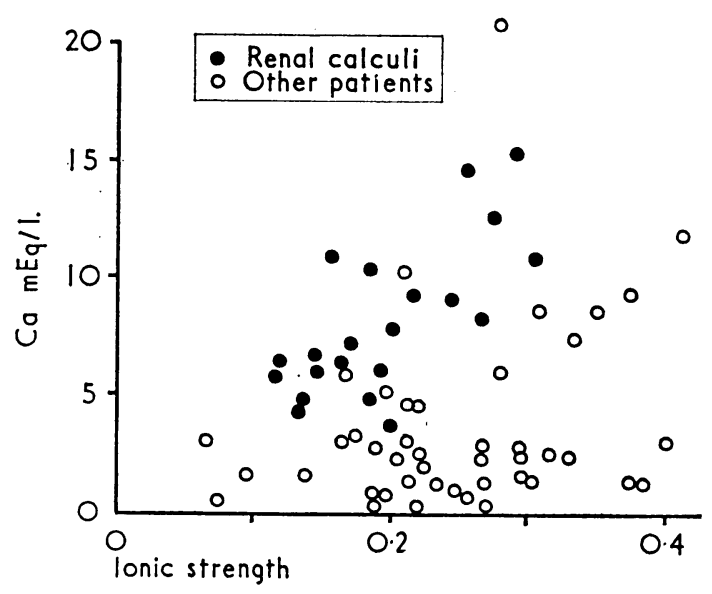

FIG. 6.-Urinary $\mathrm{Ca}$ concentrations and ionic strengths in stone-formers and in the other non-stone-forming acutely

$$
\text { ill patients. }
$$

The findings thus yield no evidence for unique abnormalities in $\mathrm{Na}$ or $\mathrm{Mg}$ (Evans, Forbes, Sutton, and Watson, 1967) excretion in nephrolithiasis, but rather confirm the original postulate (Isaacson et al., 1966) that hypercalciuria relative to the total urinary solutes underlies the genesis of calcium-containing renal stones.

The urinary solubility of calcium oxalate, one of the commonest components of renal stones, is known to vary with the ionic strength, and to be dependent on the concentrations of the major urinary solutes (Miller, Vermeulen, and Moore, 1958). The findings presented here are thus in accord with the supposition that renal stones occur in urine saturated with calcium salts.

I am indebted to Mr. M. Modlin and Professor W. P. U. Jackson for constant encouragement and support, Financial assistance was derived from the South African Council for Scientific and Industrial Research, the Wellcome Trust, and the Staff Research Fund of the University of Cape Town.

\section{REFERENCES}

Chambers, R. McK., and Dormandy, T. L. (1967). Lancet, 2, 1378.

Evans, R. A., Forbes, M. A., Sutton, R. A. L., and Watson, L. (1967). Lancet, $2,958$.

Isaacson, L. C. (1968a). Invest. Urol., 5, 406.

Isaacson, L. C. (1968b). Invest. Urol. In press.

Isaacson, L. C., Modlin, M., and Jackson, W. P. U. (1966). Brit. med. F., 2, 558 .

Miller, G. H., Vermeulen, C. W., and Moore, J. D. (1958). F. Urol. (Baltimore), 79, 607

Modlin, M. (1967). Ann. roy. Coll. Surg. Engl., 40, 155. 